\section{Evaluation and comparison of the effects of various cognitive-behavioral therapy methods on climacteric symptoms: A systematic review study}

(D) Leila Mollaahmadi1 ${ }^{1}$ (1) Afsaneh Keramat ${ }^{2}$, (1) Nasrin Changizi³, (1) Mansoureh Yazdkhasti ${ }^{4}$, ( Bahare Afshar ${ }^{5}$ IStudent Research Committee, School of Nursing and Midwifery, Shahroud University of Medical Sciences, Shahroud, Iran 2Reproductive Studies and Women's Health Research Center, Shahroud University of Medical Sciences, Shahroud, Iran ${ }^{3}$ Ministry of Health and Medical Education, Tehran, Iran 4Department of Midwifery, School of Medicine, Social Determinants of Health Research Center, Alborz University of Medical
Sciences, Karaj, Iran

${ }^{5}$ Student Research Committee, School of Nursing and Midwifery, Iran University of Medical Sciences, Tehran, Iran

\section{Abstract}

Objective: Climacteric syndrome, which is related to many symptoms, often causes discomfort in women. Non-pharmacologic treatment is one of the treatment options for affected individuals, and this syndrome can be cured with psychological treatments such as cognitive behavi therapy (CBT). The pesen sindy aimed Material and Methods: PubMed, Scopus, Cochrane, Medline, PsycINFO, and Google Scholar were searched for relevant articles published between January 1990 and August 2018. Data extraction and quality assessment were conducted by two authors.

Results: A total of 15 articles including 910 women were entered. We divided the CBT methods into two categories, face-to-face (individual and group CBT) and indirect (self-help CBT) methods. Among the three CBT approaches, three articles covered individual CBT, nine articles carried out group CBT, and in five articles, the self-help approach was used. The climacteric symptoms that improved with CBT were categorized into three groups as vasomotor symptoms, psychological symploms, and organic dsold

Conclusion: Although the indirect method is more cost-effective, it has less impact than the face-to-face method; it is better to use face-toface approaches to achieve better results, if possible. Further studies are required in this regard, particularly in the individual and self-help CBT Keywords: Climacteric, cognitive behavioral therapy, menopause, symptoms

Received: 29 December, 2018 Accepted: 5 February, 2019

\section{Introduction}

Climacteric and menopause are closely related concepts; however, they do not denote to exactly the same thing. Climacteric is the process of aging in women, including three periods. The first stage is peri-menopause, occurring within one and eight years before the beginning of menopause. A series of gradual changes occur during this period. The second period is

menopause, which is confirmed by having experienced a year of amenorrhea, and the postmenopausal stage, which is the third phase, begins when menopause is confirmed and lasts until old age (1). From a practical point of view, the term menopause globally refers to the aging process of the ovary and includes any period of peri-menopausal and postmenopausal in women (2). The climacteric period can be associated with symptoms in four different classifications: 1-vasomotor vegetative symptoms (e.g. hot flashes, night sweats, palpitations); 2- psychological symptoms (e.g. anxiety, depression, nervousness, insomnia, decreased libido, memory loss, melancholy, fatigue); 3- organic disorders (e.g. osteoporosis, cutaneous atrophy, urogenital atrophy, arthralgia, myalgia); and 4- metabolic disorders (e.g. obesity, arterial hypertension) (Table 1). The pathogenesis is related to a decline in sex hormone concentration, particularly the decrease in estrogens (3,4). Moreover, some factors such as genetic and lifestyle factors, psychological disposition and as gersolic and persona and if a key in period in women (6). years (7), and the age of menopause remains constant in spite of the increased life expectancy in women, Therefore, with an increase in life expectancy, women spend about one-thirc of their lives after menopause and have problems caused by menopausal symptoms (8). As expressed by women, they consider menopause "the beginning of new phase of life", "dissatisfaction with sexual acts" and "change in physical and mental health" (9). Thus, performing therapeutic interventions is essential to reduce the negative effect of climacteric syndrome on lifestyle

Hormone replacement therapy (HRT) is the most extensively used treatment for the main symptoms of menopause, causing a $70-90 \%$ reduction of the symptoms (10). Although HRT has been the teation of been the tre

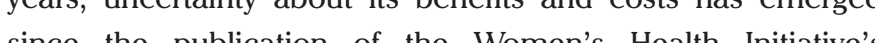

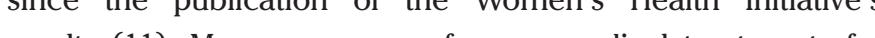
results (11). Many women prefer nonmedical trealments for menopausal symploms (12) and they are always concerned about the adverse effects and possible long-term health risks of HRT (13). Strong and convincing evidence exists indicating that the long-term risk of using estrogen and progestin to avoid postmenopausal diseases is much greater than its benefits (11). These results have challenged health providers to find alternative treatments for menopausal women (14). The evidence base for non-medical treatments is being increasingly examined with mixed results $(4,13-22$.) In addition, there has been considerable interest in developing effective nonmedical interventions to help women manage menopausal symptoms $(4,17,19,23)$.

Considering the physical and psychological problems thatoccur in this period, it seens that nonmedical herapes the help in this period, it seens the natp women to de will hir pological therapies will be usefll. Cosnitive behavioral therapy (CBT) is one or the effective methods $(24,25)$. Nowadays, CBT is used in the management of many conditions such as anxiety, depression, phobia, and stress (26). CBT-based psychological treatments were developed as treatments for menopausal disorders (21). This therapy helps people to think differently and due to this new thinking, they can confront undesirable events with more acceptable behaviors $(27,28)$. In recent studies, it was shown that cognitive behavioral treatment, including psychoeducation, paced breathing/relaxation, and CBT could help women to manage symptoms such as HF/ NS, which was acceptable to women, showed promise in exploratory trials of individual and group $\mathrm{CBT}$, and reduced the symptoms $(14,17,29)$

Various CBT methods (group, individual and self-help CBT) were implemented in the climacteric period in several trials on the health of women.

The present systematic review aimed to compare the efficacy of various methods of CBT on the improvement of the climacteric symptoms.

\section{Material and Methods}

\section{Search strategy}

The current systematic literature review was performed using electronic databases such as PubMed, Scopus, Cochrane, Medline, PsycINFO, and Google Scholar. The search was performed from January 1990 to August 2018 by using the following related keywords in tilles and abstats (women OR femele) AND (mopause* OR peri-menopacs (women OR fecte) AND (cling ( OR post "col "cognive behy (

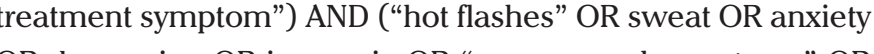

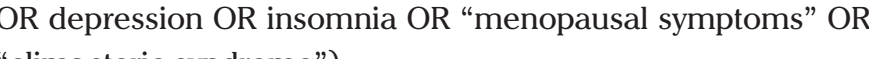
"climacteric syndrome").

Moreover, the reference section of relevant trials, systematic reviews and meta-analyses were manually checked to recognize the related trials missed by electronic database searches.

Two authors independently conducted the search and screened studies against the inclusion criteria; first, the authors independently extracted data and then checked the extracted data. Any discrepancies were resolved via discussion and consensus.

The following data were extracted with the use of PICOS criteria: population (e.g. sample size, women with natural menopause), intervention (e.g. various CBT methods: group, individual and self-help CBT, duration, length of program), comparison (e.g. non-CBT therapy group or no treatment control), outcomes (e.g. reported in the form of the improvement scores of climacteric symptoms), study design (e.g. RCT, clinical trial, quasi-experimental). Thus, the data were extracted and classified under the following headings in systematic tables (Table 1-4): author, country, year (to establish a historical timeline), study design, sample size, specifications of population, comparison condition, scale, intervention, and the main findings of the studies, which can be reported in the form of scores and changes. 


\section{Inclusion and exclusion criter}

The inclusion criteria for entering evidence in the current systematic review included original and quantitative interventional studies in English or at least with an English abstract, which could offer adequate information regarding the impact of any kind of CBT methods on the improvement of menopausal symptoms, which were published in peerreviewed jounnals Studies with randomized-controlvil, linica ial, experimental, semiexpint the enter the clim) surgery) and receing The exclusion criteria included the qualitative and quantitative interventional studies without numerical outcome data, and observational, cohort, case-control, cross-section retrospective, and prospective studies were also excluded.

\section{Screening}

A total number of 1628 articles were identified and imported to Endnote $\mathrm{X} 8$, and after removal of duplicates $(\mathrm{n}=415)$, we screened titles and abstracts of the remaining articles $(n=1213)$. After evaluating the inclusion criteria in remaining papers, the texts of 59 potentially relevant articles were fully assessed for more screening. These articles were evaluated for eligibility, me 15 these a review.

Based on the type of CBT interventions, the entered studies were classified into two groups based on the type of CBT interventions; the first classification was face-to-face CBT, including individual and group CBT, and the second was indirect CBT, containing self-help CBT. In the indirect method, the support is provided by a professional therapist by telephone, email, or any other communication tools

\section{Quality assessmen}

The quality of the studies was evaluated using the Cochrane Collaboration's tool to assess the risk of bias in randomized trials by two authors independently (27). In addition, the tool has six criteria assessed in the entered studies, which are random sequence generation, allocation concealment, description of drop-outs, blinding of participants and personel, power of drop-ons, ber an pointwas a on this assessment tool, the qually or a study was evaluated as high" when five or six chlena were observed, "moderate" when three or four criteria were observed, and "low" when fewer than three criteria were observed. Any disagreements between the two authors were discussed until consensus was reached and if any variation remained, it was settled through discussions with a third researcher.

\section{Results}

From all the related papers, based on the title and abstract screening, we can observe the inclusion criteria in 15 studies. Figure 1 represents a flow diagram of PRISMA.

\section{Characteristics of the included studies}

A total of 15 articles were published between 1996 and 2018. Among all the final articles, the designs of most studies $(n=8)$ were randomized controlled trials (RCTs) (17,19-21,31-35), three were pilot studies $(4,14,34)$, one of the remaining articles had a randomized clinical trial design (36) and two studies had a randomized clinical trial design (36), and two studies (2) also have a quasi-experimental ng the articles, two articles of Hassan (31) and Khoshbooii (32) were obtained from the
findings of one study and had similar results.

\section{Demographic characteristics of subjects}

According to the total number of subjects in all entered studies, 910 women were entered in the current systematic review. The sample size of the study population per study varied from 8 to 140 women, and the age range of the participants in the articles was assessed from 35 to 71 years.

The women involved in these studies were fairly healthy, mostly married or cohabiting, and had at least one child. Educational level was divided between those educated up to lower than primary school education, and the majority had at least phar at least pll of (in completely $(14,33)$.

\section{Methods of recruitment}

Six studies recruited participants from health centers $(17,21,31$ $33,35)$, three through Women's Health Clinics $(4,23,34)$, and five studies through general practices, breast screening clinics, menopause websites, and local newspaper advertisements $(14,19,20,37,38)$, and finally, one study recruited participants from public and private sectors (36).

The following scales were used in the entered studies to assess the symptoms changes: Insomnia Severity index BDI-II Questionnaire, Women's Health Questionn Qnestion, Anxiey, index, Hesplemrating, Center for Epidemiologic Studies Depression scale, the Greene Climactenc scale, the Montgomery-Asberg Depression Rating scale, the Hamilton Anxiety scale, Menopause Rating scale, and the Hot Flashes Related Daily Interference scale.

The number of studies based on their countries included five studies from the United Kingdom, four from the United
States, three from Iran, two from Spain, and one study from Switzerland.

\section{Quality assessmen}

In total, the six quality criteria were assessed for 15 studies. The lowest score was 1 (four studies), and the highest score was 5 (three studies). The overll sudy qulty was bw, one sudy (6\%) (hree sco was 1 (four sidy), (5) and eigh (5t\%) withalow were as follows: generation of the allocation sequence (sequence generation) was reported in zero studies, concealment of the allocation sequence (allocation concealment) was reported in 10 studies; blinding of the main outcome assessment was described in only five studies; in 10 studies, description of drop-outs was observed; a power-analysis was conducted in nine studies, and four studies had no drop-outs.

\section{Features of CBT sessions}

Generally in these articles, the CBT sessions were held to improve the following climacteric symptoms, which for

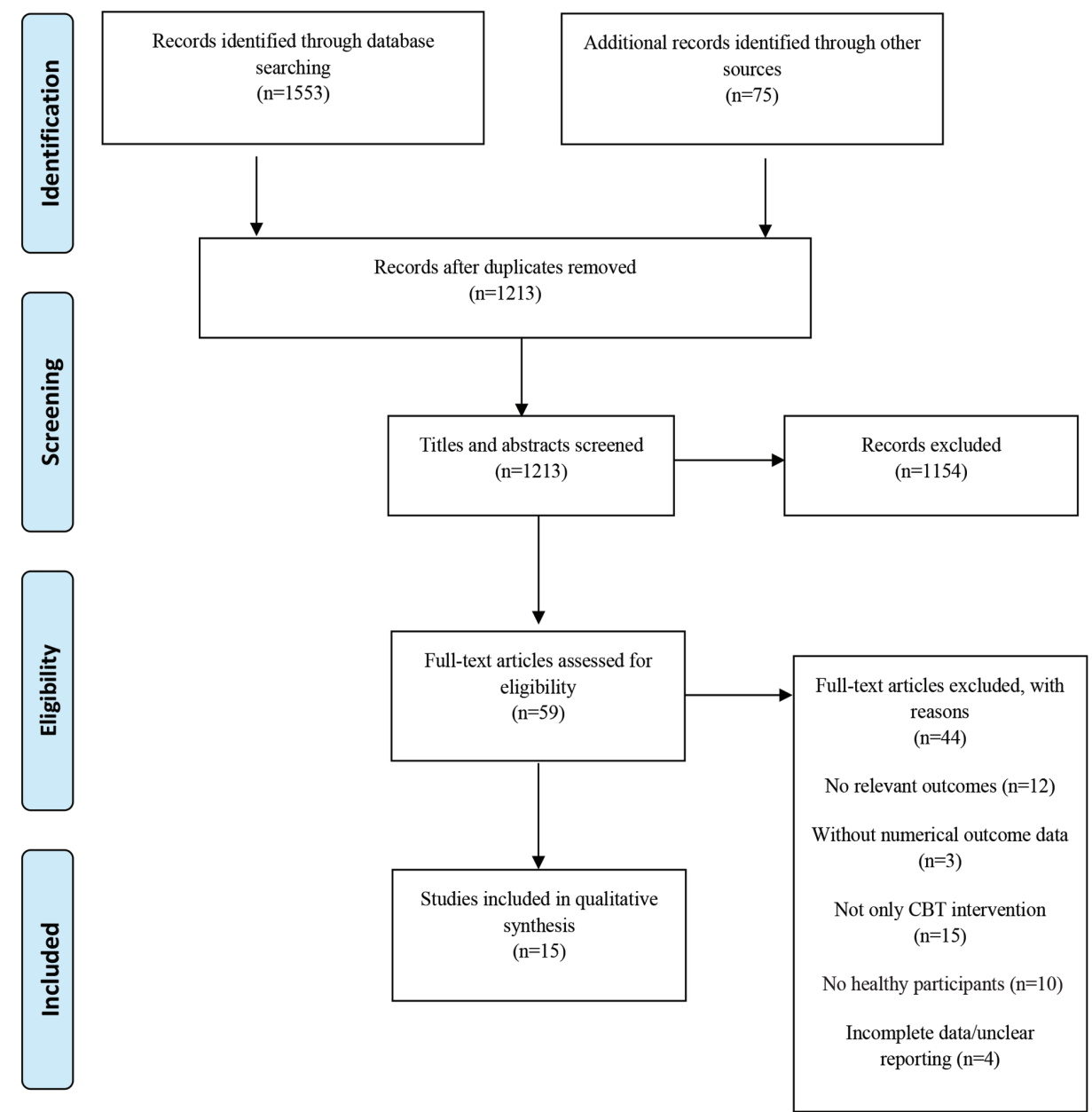
presents the classification of these symptoms.

the highest to the lowest level, were as follows: hot flashes and night sweats (HF/NS), depression, anxiety, insomnia, nervousness, melancholy, myalgia, vertigo, fatigue, irritability, headaches, palpitations, paresthesia, dysesthesia, sleeping problems, cardiac symptoms, sexual problems, urinary symptoms, vaginal dryness, and joint and muscle pain. Table 1

As mentioned earlier, in general, we divided the studies into two general classifications in terms of the CBT method used (face-to-face and indirect), where the face-to-face method includes individual CBT and group CBT. Based on the studies reporting the individual CBT, this approach was conducted in the form of 4-6 sessions of one hour per 6-8 weeks. In general, group CBT sessions consisted of 4 to 16 sessions of 60 to 160 minutes, usually held weekly, and women were in groups of 4 to 12 people. All studies considering the self-help CBT as a subset of indirect CBT used a booklet and participants had to complete this protocol during a 4-week period, and two studies, in addition to the booklet, had 2-week telephone guide 
Table 1. The classification of the climacteric symptoms improved by CB

\begin{tabular}{|l|l|l|}
\hline $\begin{array}{l}\text { Vasomotor } \\
\text { symptoms }\end{array}$ & $\begin{array}{l}\text { Psychological } \\
\text { symptoms }\end{array}$ & Organic disorder \\
\hline Hot flash & Depression & Myalgia \\
\hline Night sweat & Anxiety & Urinary complaints \\
\hline Vertigo & $\begin{array}{l}\text { Insomnia (sleeping } \\
\text { problems) }\end{array}$ & Vaginal dryness \\
\hline Headache & Nervous & Joint and muscle pain \\
\hline Palpitation & Melancholy & \\
\hline Paresthesia & Fatigue & \\
\hline Cardiac complaints & Irritability & \\
\hline & Sexual problems & \\
& \multicolumn{2}{|l|}{} \\
\hline
\end{tabular}

\section{Statistical analysis}

To assess the effect of CBT methods on climacteric symptoms and to assess clinically meaningful individual change in symptoms, symptom changes scores were calculated as follows (mean difference):

$M D=$ Pre-treatment symptom score - Last post treatment symptom score

For better a comparison between all the main results, and so as to not equalize the score before the treatment in the studies, we converted the MD score to a percentage.

Accordingly, the number in the table in percentage form represents the decrease or increase in the severity of the symptoms after the treatment (compared with the initial score).

$$
\text { Percentage }=\frac{M D}{\text { Pre-treatment symptom score }}
$$

\section{The Effect of CBT Methods on Climacteric} Symptoms

a. The effect of evaluating each CBT approach on symptoms reviewed in studies (Table 24)

HF/NS frequency

According to the findings:

Individual CBT was able to decrease the pre-test score of $\mathrm{HF} /$

NS frequency up to $59 \%$ (Table 2).

Group CBT was successful in decreasing the initial score of $\mathrm{HF} /$

NS frequency by $3.9-40 \%$ (Table 3 ).

Self-help CBT made a decline in the baseline score of $\mathrm{HF} / \mathrm{NS}$

frequency by 3.9-48\% (Table 4).

\section{HF/NS problem rating}

Individual CBT caused a 33\% reduction from the baseline score of HF/NS problem rating (Table 2).

Group CBT was able to make a 22-52\% reduction in the pre-test score of $\mathrm{HF} / \mathrm{NS}$ problem rating (Table 3 )

Self-help CBT was successful in decreasing the initial score of HF/NS problem-rating by $20-52 \%$ (Table 4).

Hot flashes

Group CBT reduced baseline score of hot flashes by 11-57\%.

Night sweats

Group CBT was not able to significantly reduce night sweats. In the study by Kefeer and Blanchard (14), group CBT reduced night sweats up to $41 \%$ in the immediate group, but the score was nearly doubled in the delay group (Table 3).

Individual CBT was able to make a 50-63\% reduction in the pretest score of depression (Table 2).

Group CBT was successful in decreasing the initial score of depression by 27-72\% (Table 3).

Anxiety

Group CBT was able to reduce baseline scores of anxiety by $18-71 \%$ (Table 3).

Individual CBT caused a 73\% reduction from the baseline score of insomnia (Table 2).

Group CBT could not only make a considerable failure in the baseline score of insomnia, but also caused a $19 \%$ increase in the pre-test score (Table 3 ).

Self-help CBT was successful in decreasing the initial score of insomnia by $71 \%$ (Table 4 ).

\section{Nervousness}

Group CBT was able to make an approximately $18 \%$ reduction in the pre-test score of nervousness in women (Table 3). Melancholy

Group CBT was successful in decreasing the initial score of melancholy up to $41 \%$.

Cardiac symptoms

Group CBT could cause a $42 \%$ reduction from the baseline score of cardiac symptoms.

Sexual problems

Group CBT was able to make a 29\% reduction in the pre-test score of sexual problems.

Vaginal dryness

Group CBT was able to reduce the pre-test score of vaginal dryness up to $29 \%$

Group CBT was not successful in decreasing the initial score of urinary symptoms and the score in the follow-up period had a $10 \%$ increase of baseline (Table 3).

\section{Joint and muscle pain}

Group CBT was successful in decreasing the initial score of joint and muscle pain up to $16 \%$.

Myalgia, vertigo, fatigue, irritability, headaches, palpitations, paresthesia, and dysesthesia

Group CBT was unable to create a considerable decline in the follow-up score of each of them, separately (Table 3).

\section{b. The effectiveness of the face-to-face CBT method}

To evaluate this method, first of all, we will determine the impact of individual and group CBT approach according to Table 2 and Table 3 and our main findings mentioned above. Individual CBT

Only three studies referred to this method, and if we determine which symptoms can be improved by this approach, $\mathrm{HF} / \mathrm{NS}$, the frequency in the vasomotor cluster can be indicated. Individual CBT can have excellent effects on insomnia, which is classified in the category of psychological symptoms. The overall findings of this approach cannot be regarded because few studies have evaluated the effects of individual CBT (Table 2).

Group CBT

Since only group therapy was conducted on each of the vasomotor symptoms separately, we can conclude that group CBT could not be successful in treating most of the vasomotor symptoms, and it just improved hot flashes and cardiac symptoms among the seven symptoms of this classification. However, it can make the HF/NS rate better than with the other approaches.

Most of the psychological symptoms (except insomnia) had a greater improvement in the group CBT approach, and only vaginal dryness in the organic disorder category could be under the effect of group CBT, and most of them did not have significantly positive changes, Generally group CBT was more effective on psychological symptoms (Table 3).

\section{c. The efficiency of indirect CBT metho}

In this part, we examine the self-help CBT approach. Self-help CBT

Self-help CBT approach has improved symptoms such as HF/ NS frequency and problem rating, but the individual approach is more effective. Also this approach had the same positive effect as individual therapy on insomnia (Table 4).

\section{Discussion}

Considering the many studies conducted to improve the menopause symptoms using group CBT, we can show that more favorable effects on psychological symptoms. However, considering the fact that apart from group therapy, other approaches have not applied to psychological symptoms and owing to the good effect of individual and self-help CBT in depression and insomnia, group CBT cannot be absolutely chosen as the best approach $(31,32)$. Moreover, limited studies were conducted on individual and self-help CBT and most of them focused on $\mathrm{HF} / \mathrm{NS}$ frequency and problem rating in each approach. Among these, individual CBT played a further role on $\mathrm{HF} / \mathrm{NS}$ frequency, which due to the limited (n) limited four fis part a be genealized (17). OBT group and selfhelp CBT also played a positive and similar role on HF/NS frequency, which resulted from more studies (33-38)

According to three articles comparing the different approaches $(19,20,32)$, two studies compared the effects of group and self-help CBT on $\mathrm{HF} / \mathrm{NS}$ frequency and problem rating. The group CBT treatment consists of psycho-education, stress management, paced breathing, and self-help CBT includes a self-help book that is learned during a four-week course and two phone calls made by a psychologist. Both of them, as already mentioned, indicated an almost equal effect of the two approaches; however, group CBT was somewhat more successfut than self-help CBT $(19,20)$, consistent with our findings.

In the study of Khoshbooii (32), the impacts of individual and group CBT on depression were compared with each other. The individual sessions are tailored to the needs of women and are flexible, but the general format of CBT sessions covered the main components such as psychoeducation, cognitive interventions, behavioral interventions, assigning homework, and relapse prevention. According to their findings, both approaches had the same effect on depression, and the effect of individual CBT was negligibly greater than group CBT (32). In addition, as mentioned earlier, both group and individual CBT had a positive and significant impact on depression but the findings from group therapy were more widespread $(32,34,35)$, which could be a result of the alterations in the conditions of the samples, the number of treatment sessions, the content or the kind of follow-up in studies; therefore, group CBT cannot be considered a gurantes; applach but if properly inplemented it can reduce up to 72\% of the initial depression score ofher it can ony be up to $27 \%$ effecive. Thus, the prefinter treatment approach for depression can be group CBT sessions held in good conditions.

Based on the findings of the present study, it can be concluded that if an individual has an insomnia problem, group CBT cannot produce a good result, but individual and self-help 


\section{Face-to-Face CBT methods}

Table 2. The efficiency of individual CBT on Climacteric symptoms

\begin{tabular}{|c|c|c|c|c|c|c|}
\hline $\begin{array}{l}\text { Author/year/ } \\
\text { country }\end{array}$ & $\begin{array}{l}\text { Study } \\
\text { design }\end{array}$ & Sample size & $\begin{array}{l}\text { Specifications of } \\
\text { population }\end{array}$ & $\begin{array}{l}\text { Comparison } \\
\text { condition }\end{array}$ & Scale & Intervention \\
\hline $\begin{array}{l}\text { Nowakowski et } \\
\text { al. (33) }\end{array}$ & $\begin{array}{l}\text { Clinical } \\
\text { trial }\end{array}$ & n total: 40 & $\begin{array}{l}\text { Mean age }=55 \pm 6.2 \\
\text { Reported } \geq 1 \text { nocturnal } \\
\text { hot flash }\end{array}$ & $\begin{array}{l}\text { MEC } \\
\text { Pre and post } \\
\text { treatment }\end{array}$ & $\begin{array}{l}\text { 1. ISI } \\
\text { 2.CES-D }\end{array}$ & $\begin{array}{l}\text { MEC and CBTMI } \\
4 \text { sessions } \\
50 \text { minute } \\
\text { over } 8 \text { weeks } \\
\text { (Pych-education } \\
\text { cognitive interventions) }\end{array}$ \\
\hline $\begin{array}{l}\text { Khoshbooii } \\
(32)\end{array}$ & RCT & $\begin{array}{l}\mathrm{n} \text { total: } 42 \\
\mathrm{n} \text { intervention: } 20 \\
\mathrm{n} \text { control: } 22\end{array}$ & $\begin{array}{l}\text { Age range: } 41-55 \\
\text { With a depression score } \\
\text { between } 21-56\end{array}$ & \begin{tabular}{|l|} 
Control group \\
Follow up periods
\end{tabular} & $\begin{array}{l}\text { BDI-II } \\
\text { Questionnaire }\end{array}$ & $\begin{array}{l}\text { (I-CBT) } \\
8 \text { sessions } \\
60 \text { minute } \\
\text { over } 8 \text { weeks } \\
\text { Skills group information } \\
\text { based on cognitive } \\
\text { behavioral assumptions }\end{array}$ \\
\hline $\begin{array}{l}\text { Hunter et al. } \\
\text { (29) }\end{array}$ & RCT & $\begin{array}{l}\text { n total: } 61 \\
\text { n CBT: } 27 \\
\text { n HRT: } 19 \\
\text { n control: } 15\end{array}$ & $\begin{array}{l}\text { Age range } 45-71 \\
\text { Women who reported hot } \\
\text { flashes (or night sweats) } \\
\text { once a week or more } \\
\text { frequently }\end{array}$ & $\begin{array}{l}\text { CBT compare } \\
\text { with HRT and no } \\
\text { treatment control } \\
\text { group (NT) } \\
\text { Follow up periods }\end{array}$ & $\begin{array}{l}\text { 1.Women's } \\
\text { Health } \\
\text { Questionnaire } \\
\text { 2. A checklist } \\
\text { for assessment } \\
\text { of hot flashes }\end{array}$ & $\begin{array}{l}4 \text { sessions } \\
60 \text { minute } \\
\text { over 6-8 weeks } \\
\text { Relaxation, rhythmic } \\
\text { breathing } \\
\text { Cognitive-behavioural to } \\
\text { cope with hot flushes }\end{array}$ \\
\hline
\end{tabular}

*SX: The abbreviation of symptoms, MEC: Menopause education control, ISI: Insomnia Severity index, CES-D: Center for epidemiologic studies depression scale,

\begin{tabular}{|c|c|c|c|c|c|c|c|}
\hline \multicolumn{8}{|c|}{ Main findings } \\
\hline \multicolumn{2}{|l|}{$\mathrm{SX}^{*}$} & \multirow{2}{*}{\begin{tabular}{|l} 
Pre-treatment \\
$15 \pm 3.5$
\end{tabular}} & \multirow{2}{*}{$\begin{array}{l}\text { Post-treatment } \\
4 \pm 3.7\end{array}$} & \multicolumn{2}{|l|}{ MD (\%) } & \multicolumn{2}{|l|}{$p$ value } \\
\hline \multirow{2}{*}{ Insomnia severity } & СвтMI & & & \multicolumn{2}{|l|}{$-11(73 \% \downarrow)$} & \multirow{2}{*}{\multicolumn{2}{|c|}{$=0.003$}} \\
\hline & MEC & $16 \pm 4.2$ & $10 \pm 5.0$ & \multicolumn{2}{|l|}{$-6(37 \% \downarrow)$} & & \\
\hline \multirow{2}{*}{ Depression } & СвTMI & $16 \pm 9.0$ & $8 \pm 7.4$ & $-6(37 \% \downarrow)$ & & \multirow{2}{*}{\multicolumn{2}{|c|}{$=0.019$}} \\
\hline & MEC & $15 \pm 11.1$ & $13 \pm 9.2$ & \multicolumn{2}{|l|}{$-2(13 \% \downarrow)$} & & \\
\hline \multicolumn{2}{|l|}{$\mathrm{SX}^{*}$} & Pre- test & Post test & 4 weeks & MD (\%) & \multicolumn{2}{|l|}{ p value } \\
\hline \multirow{2}{*}{ Depression } & I & $32.30 \pm 8.73$ & $10.85 \pm 6.17$ & $11.75 \pm 6.59$ & $-20.55(63 \% \downarrow)$ & \multirow{2}{*}{\multicolumn{2}{|c|}{$=0.001$}} \\
\hline & C & $34.09 \pm 8.34$ & $32.77 \pm 6.92$ & $33.77 \pm 7.17$ & $-0.32(0.9 \% \downarrow)$ & & \\
\hline \multicolumn{2}{|l|}{ sx } & Baseline & Monitor & Post-treatment & Follow-up & MD (\%) & p value \\
\hline \multirow{3}{*}{ HF/NS frequency } & CBT & $28.08 \pm 21.06$ & $28.87 \pm 25.41$ & $14.37 \pm 16.47$ & $11.41 \pm 17.52$ & $-16.67(59 \% \downarrow)$ & $<0.01$ \\
\hline & HRT & $42.92 \pm 33.46$ & $37.25 \pm 35.43$ & $11.75 \pm 14.63$ & $9.50 \pm 14.06$ & $-33.42(77 \% \downarrow)$ & $<0.01$ \\
\hline & Control & $24.19 \pm 19.65$ & $22.19 \pm 18.14$ & $23.19 \pm 16.26$ & $20.07 \pm 17.87$ & $-4.12(17 \% \downarrow)$ & $>0.05$ \\
\hline \multirow{3}{*}{ HF/NS problem } & CBT & $5.49 \pm 2.58$ & $5.28 \pm 2.37$ & $3.13 \pm 1.77$ & $3.65 \pm 2.39$ & $-1.84(33 \% \downarrow)$ & $<0.01$ \\
\hline & HRT & $5.36 \pm 1.98$ & $5.33 \pm 2.47$ & $5.13 \pm 1.39$ & $5.23 \pm 2.04$ & $-0.13(2.4 \% \downarrow)$ & $>0.05$ \\
\hline & Control & $4.21 \pm 1.83$ & $3.32 \pm 1.63$ & $3.82 \pm 1.71$ & $3.82 \pm 2.23$ & $-0.39(9.2 \% \downarrow)$ & $>0.05$ \\
\hline
\end{tabular}




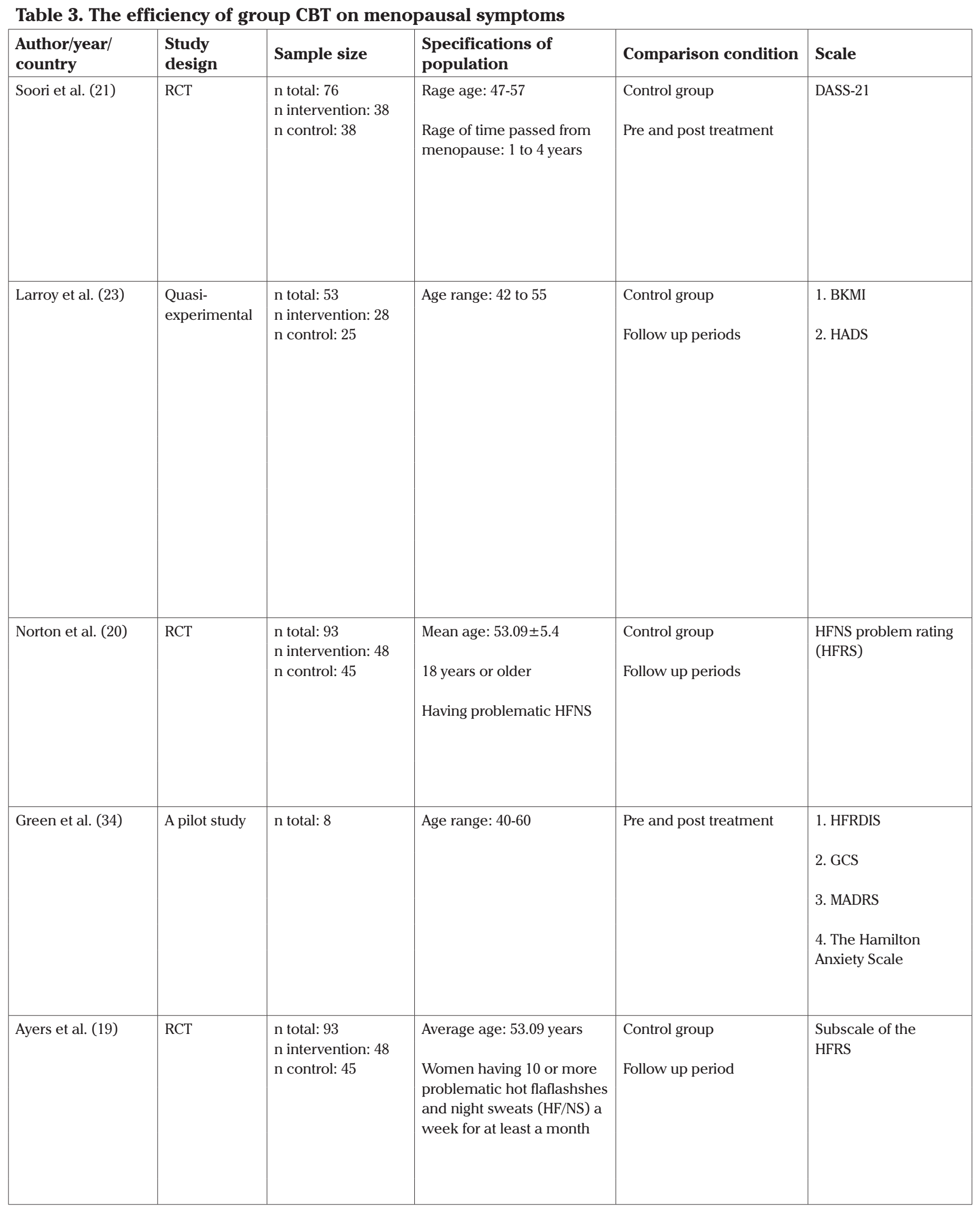

\begin{tabular}{|c|c|c|c|c|c|c|c|}
\hline \multirow{4}{*}{ 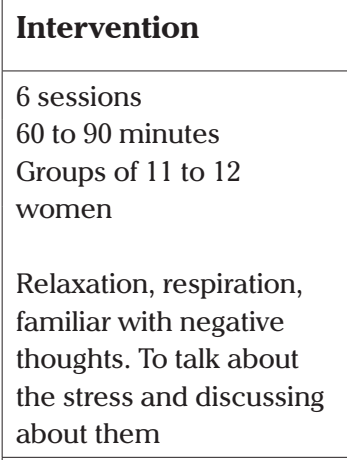 } & \multicolumn{7}{|c|}{ Main findings } \\
\hline & \multicolumn{2}{|l|}{$\mathrm{SX}^{*}$} & \multirow{2}{*}{\begin{tabular}{|l} 
Pre-treatment \\
$9.63 \pm 3.72$
\end{tabular}} & \multirow{2}{*}{$\begin{array}{l}\text { Post-treatment } \\
2.63 \pm 1.97\end{array}$} & \multirow{2}{*}{$\begin{array}{l}\mathbf{1} \text { month later } \\
2.35 \pm 1.66\end{array}$} & \multirow{2}{*}{\begin{tabular}{|l|} 
MD (\%) \\
$-7.01(72 \% \downarrow)$
\end{tabular}} & \multirow{2}{*}{$\begin{array}{l}\text { p value } \\
<0.001\end{array}$} \\
\hline & \multirow[b]{2}{*}{ Depression } & I & & & & & \\
\hline & & C & $8.50 \pm 3.42$ & $7.81 \pm 3.97$ & $7.44 \pm 2.66$ & $-1.06(12 \% \downarrow)$ & $>0.05$ \\
\hline \multirow{4}{*}{$\begin{array}{l}8 \text { sessions } \\
120 \text { minutes } \\
\text { weekly } \\
\text { Groups of } 8-10 \text { women }\end{array}$} & \multicolumn{2}{|l|}{$S X^{*}$} & Pre- test & Post test & MD (\%) & \multicolumn{2}{|l|}{ p value } \\
\hline & \multirow{2}{*}{ Hot flashes } & I & $8.29 \pm 3.91$ & $4.29 \pm 3.76$ & $-4(48 \% \downarrow)$ & \multicolumn{2}{|l|}{$<0.001$} \\
\hline & & C & $10.4 \pm 2.58$ & $10.8 \pm 2.86$ & $0.40(3.8 \% \uparrow)$ & \multicolumn{2}{|l|}{$>0.05$} \\
\hline & \multirow{2}{*}{ Nervous } & I & $4.46 \pm 1.64$ & $3.64 \pm 2.04$ & $-0.82(18 \% \downarrow)$ & $<0.05$ & \\
\hline \multirow{9}{*}{$\begin{array}{l}\text { Psycho education, } \\
\text { relaxation, exercise and } \\
\text { nutrition, Kegel exercises. } \\
\text { Sexual re-education, } \\
\text { problem-solving }\end{array}$} & & C & $3.40 \pm 1.91$ & $3.60 \pm 2.00$ & $0.20(5.8 \% \uparrow)$ & \multicolumn{2}{|l|}{$>0.05$} \\
\hline & \multirow{2}{*}{ Melancholia } & I & $2.14 \pm 0.93$ & $1.25 \pm 0.84$ & $-0.89(41 \% \downarrow)$ & \multicolumn{2}{|l|}{$<0.001$} \\
\hline & & C & $1.68 \pm 1.18$ & $1.60 \pm 1.19$ & $0.80(47 \% \uparrow)$ & $>0.05$ & \\
\hline & \multirow{2}{*}{ Anxiety } & I & $11.79 \pm 3.05$ & $8.14 \pm 3.19$ & $-3.58(30 \% \downarrow)$ & \multicolumn{2}{|l|}{$<0.001$} \\
\hline & & C & $10.60 \pm 1.98$ & $10.28 \pm 1.43$ & $-0.32(3 \% \downarrow)$ & \multicolumn{2}{|l|}{$>0.05$} \\
\hline & \multirow{2}{*}{ Depression } & I & $6.71 \pm 3.71$ & $4.79 \pm 2.63$ & $-1.92(28 \% \downarrow)$ & \multicolumn{2}{|l|}{$<0.001$} \\
\hline & & C & $4.65 \pm 3.69$ & $4.88 \pm 3.39$ & $0.23(4.9 \% \uparrow)$ & \multirow{2}{*}{\multicolumn{2}{|c|}{$>0.05$}} \\
\hline & \multirow{2}{*}{$\begin{array}{l}\text { Intensity of } \\
\text { symptom }\end{array}$} & I & $28.75 \pm 5.75$ & $19.36 \pm 8.62$ & $-9.39(32 \% \downarrow)$ & & \\
\hline & & $\mathbf{C}$ & $28.88 \pm 6.63$ & $28.48 \pm 5.97$ & $-0.40(1.3 \% \downarrow)$ & \multicolumn{2}{|l|}{$\begin{array}{l}<0.001 \\
>0.05\end{array}$} \\
\hline & $\mathrm{sx}$ & & Baseline & 6 weeks & 26 weeks & MD (\%) & $\mathrm{p}$ value \\
\hline $\begin{array}{l}\text { Weekly } 160 \text { minutes } \\
\text { Groums of } 6-8 \text { women }\end{array}$ & & I & $5.87 \pm 2.28$ & $3.75 \pm 0.76$ & $4.54 \pm 0.8$ & $-1.33(22 \% \downarrow)$ & \\
\hline Received a relaxation/ & $\begin{array}{l}\text { HFFN problem } \\
\text { rating }\end{array}$ & C & $5.87 \pm 2.28$ & $\begin{array}{l}\text { Not significant } \\
\text { difference }\end{array}$ & $\begin{array}{l}\text { Not significant } \\
\text { difference }\end{array}$ & & $=0.001$ \\
\hline paced brea & HF/NS & I & $63.15 \pm 49.24$ & \begin{tabular}{|l|}
$60.67 \pm 1.61$ \\
Small significant
\end{tabular} & eduction & $-2.48(3.9 \% \downarrow)$ & $<005$ \\
\hline & frequency & C & $63.15 \pm 49.24$ & $\begin{array}{l}\text { Not significant } \\
\text { difference }\end{array}$ & $\begin{array}{l}\text { Not significant } \\
\text { difference }\end{array}$ & & a $<0.00$ \\
\hline $\begin{array}{l}10 \text { session } \\
\text { Weekly }\end{array}$ & sx & $\begin{array}{l}\begin{array}{l}\text { Pre- } \\
\text { treatment }\end{array} \\
\end{array}$ & Post-treatment & MD (\%) & & $p$ value & \\
\hline $\begin{array}{l}160 \text { minutes } \\
\text { Groups of } 4\end{array}$ & $\begin{array}{l}\text { Hot flash daily } \\
\text { interference }\end{array}$ & $39.8 \pm 12.4$ & $16.9 \pm 9.5$ & $-22.90(57 \% \downarrow)$ & & $=0.01$ & \\
\hline $\begin{array}{l}\text { Psychoeduca } \\
\text { Psin }\end{array}$ & Anxiety & $19.8 \pm 6.0$ & $12.8 \pm 6.7$ & $-7(35 \% \downarrow)$ & & $=0.00$ & \\
\hline cognitive, restructuring, & Depression & $6.9 \pm 3.6$ & $4.6 \pm 4.1$ & $-2.3(33 \% \downarrow)$ & & $=0.04$ & \\
\hline $\begin{array}{l}\text { relaxation, Behavioral } \\
\text { modification for } \\
\text { urogenital complaints }\end{array}$ & \begin{tabular}{|l} 
Variety of \\
menopausal \\
symptoms
\end{tabular} & $23.1 \pm 10.7$ & $19.0 \pm 13.7$ & $-4.1(17 \% \downarrow)$ & & $=0.19$ & \\
\hline $\begin{array}{l}4 \text { session } \\
\text { Whoplvy } 160 \text { mi }\end{array}$ & $\mathrm{sx}$ & & Baseline & 6 weeks & 26 weeks & MD (\%) & $p$ value \\
\hline Groups of 4 women & HF/NS problem & I & $6.00 \pm 2.15$ & $3.01 \pm 2.11$ & $2.86 \pm 2.11$ & $-3.14(52 \% \downarrow)$ & $=0.001$ \\
\hline $\begin{array}{l}\text { Using PowerPoint } \\
\text { presentations, a }\end{array}$ & & C & $5.79 \pm 2.76$ & $4.97 \pm 2.44$ & $4.18 \pm 2.45$ & $-1.61(27 \% \downarrow)$ & \\
\hline $\begin{array}{l}\text { relaxation/paced } \\
\text { breathing CD, and }\end{array}$ & $\begin{array}{l}\text { HF/NS } \\
\text { frequency }\end{array}$ & I & $61.83 \pm 38.17$ & $43.85 \pm 42.16$ & $36.77 \pm 50.71$ & $-25.06(40 \% \downarrow)$ & $=0.004$ \\
\hline handouts & & $\mathbf{C}$ & $56.69 \pm 50.43$ & $49.67 \pm 48.55$ & $44.05 \pm 45.18$ & $-12.64(22 \% \downarrow)$ & \\
\hline
\end{tabular}




\begin{tabular}{|c|c|c|c|c|c|}
\hline $\begin{array}{l}\text { Author/year/ } \\
\text { country }\end{array}$ & \begin{tabular}{|l|} 
Study \\
design
\end{tabular} & Sample size & $\begin{array}{l}\text { Specifications of } \\
\text { population }\end{array}$ & Comparison condition & Scale \\
\hline Khoshbooii (32) & RCT & \begin{tabular}{|l} 
n total: 44 \\
n intervention: 22 \\
n control: 22
\end{tabular} & $\begin{array}{l}\text { Aged range: } 41-55 \\
\text { With a depression score } \\
\text { between } 21 \text { and } 56\end{array}$ & $\begin{array}{l}\text { Control group } \\
\text { Pre and post treatment + } \\
\text { follow up }\end{array}$ & BDI-II Questionnaire \\
\hline $\begin{array}{l}\text { Larroy García and } \\
\text { Gómez-Calcerrada } \\
\text { (4) }\end{array}$ & A pilot study & \begin{tabular}{|l} 
n total: 49 \\
$\mathrm{n}$ intervention: 21 \\
$\mathrm{n}$ control: 28
\end{tabular} & Range age: $43-56$ & \begin{tabular}{|l|} 
Control group \\
Pre and post treatment
\end{tabular} & $\begin{array}{l}\text { 1. HADS } \\
\text { 2.Kupperman and } \\
\text { Blatt Menopausal } \\
\text { Index }\end{array}$ \\
\hline
\end{tabular}

\begin{tabular}{|c|c|c|c|c|c|c|c|}
\hline \multirow{4}{*}{$\begin{array}{l}\text { Intervention } \\
16 \text { sessions } \\
\text { twice weekly } \\
160 \text { minutes } \\
\text { Psycho-education } \\
\text { Cognitive Interventions } \\
\text { Behavioral Intervention } \\
\end{array}$} & \multicolumn{7}{|c|}{ Main findings } \\
\hline & \multicolumn{2}{|l|}{ sx } & Pre-test & Post test & 4 weeks & MD (\%) & p value \\
\hline & \multirow[b]{2}{*}{ Depression } & I & $33.95 \pm 9.64$ & $12.04 \pm 5.89$ & $12.63 \pm 6.41$ & $-21.32(62 \% \downarrow)$ & \multirow[b]{2}{*}{$=0.001$} \\
\hline & & C & $34.09 \pm 8.34$ & $32.77 \pm 6.92$ & $33.77 \pm 7.17$ & $-1.13(3.3 \% \downarrow)$ & \\
\hline \multirow{29}{*}{\begin{tabular}{|l}
8 sessions \\
weekly \\
160 minutes \\
\\
Psycho education, \\
relaxation, Kegel \\
exercises, and problem- \\
solving techniques
\end{tabular}} & \multicolumn{2}{|l|}{ sx } & Pre-treatment & Post-treatment & MD (\%) & \multicolumn{2}{|l|}{ p value } \\
\hline & \multirow{2}{*}{ Anxiety } & I & $6.43 \pm 4.3$ & $5.24 \pm 3.40$ & $-1.19(18 \% \downarrow)$ & \multirow{2}{*}{\multicolumn{2}{|c|}{$\begin{array}{l}<0.010 \\
>005\end{array}$}} \\
\hline & & C & $10.60 \pm 1.98$ & $10.28 \pm 1.43$ & $-0.32(3 \% \downarrow)$ & $>0.05$ & \\
\hline & \multirow{2}{*}{ Depression } & I & $4.05 \pm 3.19$ & $2.76 \pm 2.98$ & $-1.29(31 \% \downarrow)$ & \multicolumn{2}{|l|}{$<0.025$} \\
\hline & & C & $4.72 \pm 3.69$ & $4.88 \pm 3.39$ & $0.16(3.3 \% \uparrow)$ & \multirow{2}{*}{\multicolumn{2}{|c|}{$\begin{array}{l}>0.05 \\
<0.030\end{array}$}} \\
\hline & \multirow{2}{*}{\begin{tabular}{|l|} 
Intensity of \\
symptoms
\end{tabular}} & I & $14.14 \pm 7.03$ & $11.24 \pm 6.47$ & $-2.9(20 \% \downarrow)$ & & \\
\hline & & C & $28.88 \pm 6.66$ & $28.48 \pm 5.97$ & $-0.40(1.3 \% \downarrow)$ & \multicolumn{2}{|l|}{$>0.05$} \\
\hline & \multirow{2}{*}{ Hot flashes } & I & \multicolumn{2}{|c|}{ Not significant difference } & & \multicolumn{2}{|l|}{$>0.05$} \\
\hline & & C & \multicolumn{2}{|c|}{ Not significant difference } & & \multicolumn{2}{|l|}{$>0.05$} \\
\hline & \multirow{2}{*}{ Paresthesia } & I & \multirow{2}{*}{\multicolumn{2}{|c|}{\begin{tabular}{|l} 
Not significant difference \\
Not significant difference
\end{tabular}}} & & \multicolumn{2}{|l|}{$>0.05$} \\
\hline & & C & & & & \multicolumn{2}{|l|}{$>0.05$} \\
\hline & \multirow{2}{*}{ Insomnia } & I & \multirow{2}{*}{\multicolumn{2}{|c|}{\begin{tabular}{|l} 
Not significant difference \\
Not significant difference
\end{tabular}}} & & \multicolumn{2}{|l|}{$>0.05$} \\
\hline & & C & & & & $>0.05$ & \\
\hline & Neryousness & I & Not significant c & erence & & $>0.05$ & \\
\hline & Nervousness & C & Not significant c & erence & & $>0.05$ & \\
\hline & Melancholv & I & Not significant $\mathrm{c}$ & erence & & $>0.05$ & \\
\hline & & C & Not significant c & erence & & $>0.05$ & \\
\hline & Vertion & I & Not significant c & erence & & $>0.05$ & \\
\hline & verugo & C & Not significant c & erence & & $>0.05$ & \\
\hline & Fatioue & I & Not significant c & erence & & $>0.05$ & \\
\hline & Taugue & C & Not significant $\mathrm{C}$ & erence & & $>0.05$ & \\
\hline & Mvaloia & I & Not significant c & erence & & $>0.05$ & \\
\hline & 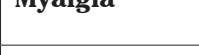 & C & Not significant $\mathrm{c}$ & erence & & $>0.05$ & \\
\hline & & I & Not significant c & erence & & $>0.05$ & \\
\hline & Headaches & C & Not significant c & erence & & $>0.05$ & \\
\hline & & I & Not significant c & erence & & $>0.05$ & \\
\hline & Palpitations & C & Not significant c & erence & & $>0.05$ & \\
\hline & Dysaesthesia & I & Not significant c & erence & & $>0.05$ & \\
\hline & Dysatsulesia & C & Not significant $\mathrm{C}$ & erence & & $>0.05$ & \\
\hline
\end{tabular}




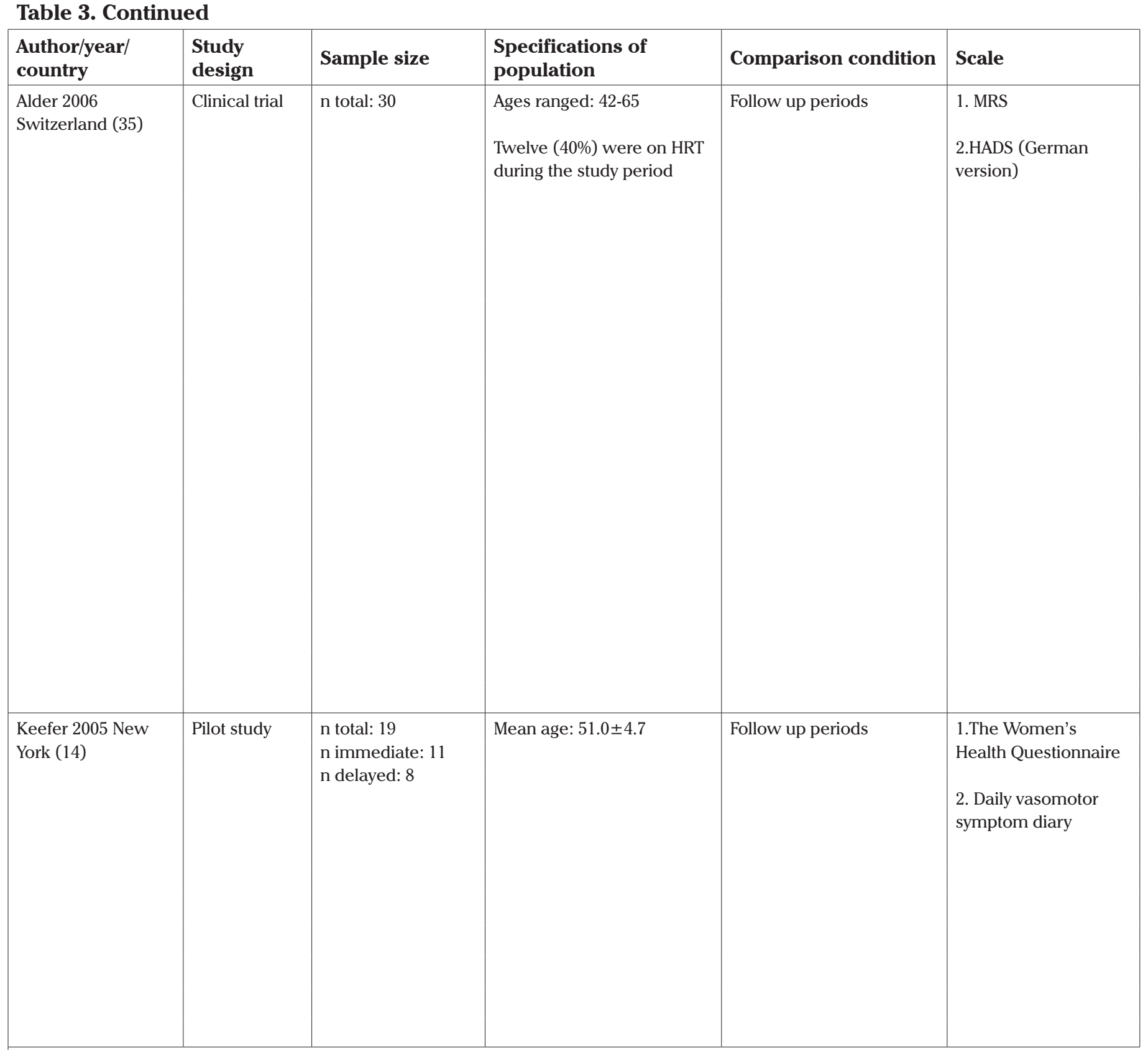

GCS: The Greene Climacteric Scale, MADRS: Montgomery-Asberg Depression Rating Scale, HADS: Hospital Anxiety and Depression Scale, BKMI: Blat's Kupperman Menopausal Index, HFNS: Hot flashes and night sweats, HFRDIS: The Hot Flash related Daily Interference Scale

\begin{tabular}{|c|c|c|c|c|c|c|}
\hline \multirow{5}{*}{\begin{tabular}{|l} 
Intervention \\
7 sessions weekly \\
90 minutes \\
Groups of $4-8$ women \\
Relaxation techniques, \\
breathing, Exercise \\
for coping with sexual \\
problem one follow-up \\
group session 3 months \\
after the intervention
\end{tabular}} & \multicolumn{6}{|c|}{ Main findings } \\
\hline & sx & \begin{tabular}{|l} 
T1 \\
10 weeks \\
before
\end{tabular} & \begin{tabular}{|l} 
T2 \\
before \\
beginning
\end{tabular} & \begin{tabular}{|l} 
T3 \\
after last \\
session
\end{tabular} & MD (\%) & p value \\
\hline & Hot flashes & $4.3 \pm 2.2$ & $3.4 \pm 2.0$ & $2.6 \pm 1.7$ & $-1.7(39 \% \downarrow)$ & $<0.01$ \\
\hline & $\begin{array}{l}\text { Cardiac } \\
\text { complaints }\end{array}$ & $1.4 \pm 1.7$ & $1.7 \pm 2.1$ & $0.8 \pm 0.6$ & $-0.6(42 \% \downarrow)$ & $<0.01$ \\
\hline & $\begin{array}{l}\text { Sleeping } \\
\text { problems }\end{array}$ & $3.1 \pm 2.5$ & $3.3 \pm 1.9$ & $3.7 \pm 4.8$ & $0.6(19 \% \uparrow)$ & N.S.** \\
\hline & $\begin{array}{l}\text { Depressive } \\
\text { mood }\end{array}$ & $3.6 \pm 2.5$ & $3.8 \pm 2.8$ & $2.6 \pm 2.2$ & $-1(27 \% \downarrow)$ & $<0.02$ \\
\hline & Irritability & $3.4 \pm 2.2$ & $4.1 \pm 2.5$ & $3.2 \pm 2.4$ & $-0.2(5.8 \% \downarrow)$ & N.S \\
\hline & $\begin{array}{l}\text { Reduced } \\
\text { effectiveness }\end{array}$ & $3.8 \pm 2.3$ & $4.2 \pm 2.7$ & $3.2 \pm 2.3$ & $-0.6(15 \% \downarrow)$ & $<0.04$ \\
\hline & $\begin{array}{l}\text { Sexual } \\
\text { problems }\end{array}$ & $4.8 \pm 3.1$ & $4.3 \pm 3.2$ & $3.4 \pm 2.7$ & $-1.4(29 \% \downarrow)$ & 0.06 \\
\hline & $\begin{array}{l}\text { Urinary } \\
\text { complaints }\end{array}$ & $1.0 \pm 1.3$ & $1.4 \pm 1.4$ & $1.1 \pm 1.2$ & $0.1(10 \% \uparrow)$ & N.S \\
\hline & $\begin{array}{l}\text { Vaginal } \\
\text { dryness }\end{array}$ & $4.1 \pm 3.5$ & $4.0 \pm 3.0$ & $2.9 \pm 2.5$ & $-1.2(29 \% \downarrow)$ & $<0.03$ \\
\hline & $\begin{array}{l}\text { Joint and } \\
\text { muscle pain }\end{array}$ & $3.1 \pm 2.6$ & $2.7 \pm 2.1$ & $2.6 \pm 2.0$ & $-0.5(16 \% \downarrow)$ & N.S \\
\hline & Anxiety & $7.7 \pm 4.5$ & $8.2 \pm 4.8$ & $6.2 \pm 4.2$ & $-1.5(19 \% \downarrow)$ & $<0.01$ \\
\hline & Depression & $5.8 \pm 4.4$ & $6.7 \pm 5.4$ & $4.7 \pm 3.9$ & $-1.1(18 \% \downarrow)$ & $<0.02$ \\
\hline \multirow{4}{*}{$\begin{array}{l}\text { Participants were } \\
\text { randomized into either } \\
\text { immediate treatment or } \\
\text { delayed treatment }\end{array}$} & \multicolumn{2}{|l|}{ sx } & Pre-treatment & Post-treatment & MD (\%) & p value \\
\hline & \multirow{2}{*}{ Hot flashes } & Immediate & $65.63 \pm 71.06$ & $37.81 \pm 58.44$ & $-27.82(42 \% \downarrow)$ & \multirow{2}{*}{$=0.21$} \\
\hline & & Delayed & $66.54 \pm 60.63$ & $58.75 \pm 95.13$ & $-7.79(11 \% \downarrow)$ & \\
\hline & \multirow{2}{*}{ Night sweats } & Immediate & $11.73 \pm 8.76$ & $6.91 \pm 8.25$ & $-4.82(41 \% \downarrow)$ & \multirow{2}{*}{$=0.09$} \\
\hline \multirow{6}{*}{$\begin{array}{l}\text { Immediate group } \\
\text { treatment } 8 \text { sessions } \\
\text { weekly } 90 \text { minutes } \\
\text { Groups of } 4-6 \text { women. } \\
\text { Psychoeducation, } \\
\text { cognitive restructuring } \\
\text { and paced respiration } \\
\text { education }\end{array}$} & & Delayed & $32.89 \pm 23.47$ & $68.00 \pm 88.12$ & $35.11(>100 \% \uparrow)$ & \\
\hline & Distress rating & \begin{tabular}{|l|} 
Immediate \\
Delayed
\end{tabular} & \begin{tabular}{|l|}
$3.18 \pm 2.22$ \\
$4.86 \pm 1.48$
\end{tabular} & $\begin{array}{l}2.59 \pm 2.71 \\
5.15 \pm 1.60\end{array}$ & \begin{tabular}{|l}
$-1.19(31 \% \downarrow)$ \\
$0.29(6.3 \% \uparrow \uparrow$
\end{tabular} & $=0.06$ \\
\hline & \multirow{2}{*}{ Problem rating } & Immediate & $4.42 \pm 1.97$ & $2.72 \pm 2.79$ & $-1.7(38 \% \downarrow)$ & \multirow{2}{*}{$=0.18$} \\
\hline & & Delayed & $9.17 \pm 12.97$ & $3.83 \pm 1.78$ & $-5.34(58 \% \downarrow)$ & \\
\hline & \multirow{2}{*}{$\begin{array}{l}\text { Total } \\
\text { vasomotor }\end{array}$} & Immediate & $78.27 \pm 44.73$ & $44.73 \pm 62.43$ & $-33.54(42 \% \downarrow)$ & \multirow{2}{*}{$=0.01$} \\
\hline & & Delayed & $98.50 \pm 64.98$ & $126.75 \pm 121.85$ & $28.25(28 \% \uparrow)$ & \\
\hline
\end{tabular}




\section{Indirect CBT methods}

Table 4. The efficiency of self-help CBT on menopausal symptoms

\begin{tabular}{|c|c|c|c|c|c|}
\hline $\begin{array}{l}\text { Author/year/ } \\
\text { country }\end{array}$ & \begin{tabular}{|l} 
Study \\
design
\end{tabular} & Sample size & Specifications of population & $\begin{array}{l}\text { Comparison } \\
\text { condition }\end{array}$ & Scale \\
\hline Hardy et al. (36) & $\begin{array}{l}\text { Multicenter } \\
\text { randomized } \\
\text { controlled trial }\end{array}$ & $\begin{array}{l}\mathrm{n} \text { total: } 124 \\
\mathrm{n} \text { intervention: } \\
60 \\
\mathrm{n} \text { control: } 64\end{array}$ & $\begin{array}{l}\text { Range age: } 45-60 \\
\text { Working women } \\
\text { Having problematic HF/NS for at least } 2 \text { months }\end{array}$ & $\begin{array}{l}\text { Control group } \\
\text { Follow-up period }\end{array}$ & $\begin{array}{l}\text { Hot flash } \\
\text { rating } \\
\text { scale as } \\
\text { used in the } \\
\text { MENOS2 } \\
\text { trial }\end{array}$ \\
\hline $\begin{array}{l}\text { McCurry et al. } \\
\text { (37) }\end{array}$ & $\begin{array}{l}\text { A single-site, } \\
\text { randomized } \\
\text { clinical trial }\end{array}$ & $\begin{array}{l}\text { n total: } 106 \\
\mathrm{n} \text { CBT: } 53 \\
\mathrm{n} \text { MEC: } 53\end{array}$ & $\begin{array}{l}\text { Range age: 40-65 } \\
\text { With moderate insomnia symptoms [(ISI) score, } \\
\geq 12 \text { ] and } 2 \text { or more daily hot flashes }\end{array}$ & $\begin{array}{l}\text { MEC } \\
\text { Follow-up periods }\end{array}$ & ISI score \\
\hline $\begin{array}{l}\text { Stefanopoulou } \\
\text { and Hunter (38) }\end{array}$ & RCT & $\begin{array}{l}\mathrm{n} \text { total: } 92 \\
\mathrm{n} \text { intervention: } \\
47 \\
\mathrm{n} \text { control: } 45\end{array}$ & $\begin{array}{l}\text { Range age: } 44-77 \\
\text { age from } 18 \text { years or older } \\
\\
\text { With problematic hot flashes and night sweats (HF/ } \\
\text { NS score }>2 \text { ) for at least } 1 \text { month and minimum } \\
\text { frequency of } 10 \text { flashes per week }\end{array}$ & $\begin{array}{l}\text { Control group } \\
\text { Follow-up periods }\end{array}$ & HFRS \\
\hline $\begin{array}{l}\text { Norton et al. } \\
(20)\end{array}$ & RCT & $\begin{array}{l}\mathrm{n} \text { total: } 92 \\
\mathrm{n} \text { intervention: } \\
47 \\
\mathrm{n} \text { control: } 45\end{array}$ & $\begin{array}{l}\text { Mean age: } 53.09 \pm 5.4 \\
18 \text { years or older } \\
\text { Having problematic HFNS (score }>2 \text { ) }\end{array}$ & $\begin{array}{l}\text { Control group } \\
\text { Follow-up periods }\end{array}$ & $\begin{array}{l}\text { HFNS } \\
\text { problem } \\
\text { rating } \\
\text { (HFRS) }\end{array}$ \\
\hline Ayers et al. (19) & RCT & $\begin{array}{l}\mathrm{n} \text { total: } 92 \\
\mathrm{n} \text { intervention: } \\
47 \\
\mathrm{n} \text { control: } 45\end{array}$ & $\begin{array}{l}\text { Average age: } 53.09 \text { years } \\
\text { Women having } 10 \text { or more problematic hot flashes } \\
\text { and night sweats a week for at least a month }\end{array}$ & $\begin{array}{l}\text { Control group } \\
\text { Follow-up periods }\end{array}$ & $\begin{array}{l}\text { Subscale of } \\
\text { the } \\
\text { HFRS }\end{array}$ \\
\hline
\end{tabular}

GCS: The Greene Climacteric Scale, MADRS: Montgomery-Asberg Depression Rating Scale, HADS: Hospital Anxiety and Depression Scale, BKMI: Blat's Kupperman Menopausal Index, HFNS: Hot flashes and night sweats, HFRDIS: The Hot Flash related Daily Interference Scale

\begin{tabular}{|c|c|c|c|c|c|c|c|}
\hline \multirow{2}{*}{\begin{tabular}{|l|} 
Intervention \\
$\begin{array}{l}\text { Self-help cognitive behavior } \\
\text { therapy }\end{array}$
\end{tabular}} & \multicolumn{7}{|c|}{ Improvement score } \\
\hline & \multicolumn{2}{|l|}{ SX $\mathbf{X}^{*}$} & \multirow{2}{*}{\begin{tabular}{|l|} 
Baseline \\
$6.25 \pm 1.97$ \\
\end{tabular}} & \multirow{2}{*}{$\begin{array}{l}6 \text { weeks } \\
4.38 \pm 2.21 \\
\end{array}$} & \multirow{2}{*}{$\begin{array}{l}20 \text { weeks } \\
4.36 \pm 2.29 \\
\end{array}$} & \multirow{2}{*}{$\begin{array}{l}\text { MD (\%) } \\
-1.89(30 \% \downarrow)\end{array}$} & \multirow{3}{*}{$\begin{array}{l}\text { p value } \\
6 w: p<0.001 \\
\text { 20w: } p=0.01\end{array}$} \\
\hline \multirow{4}{*}{$\begin{array}{l}\text { The final SH-CBT intervention was } \\
\text { an A5 sized, color booklet with } \\
\text { instructions and four chapters } \\
\text { (with information, exercises } \\
\text { and homework tasks) to be } \\
\text { completed over } 4 \text { weeks }\end{array}$} & \multirow{2}{*}{\begin{tabular}{|l|} 
HF/NS \\
problem \\
rating
\end{tabular}} & I & & & & & \\
\hline & & c & $6.80 \pm 1.90$ & $6.16 \pm 2.31$ & $5.80 \pm 2.30$ & $-1(14 \% \downarrow)$ & \\
\hline & \multirow{2}{*}{$\begin{array}{l}\text { HF/NS } \\
\text { frequency }\end{array}$} & I & $53.13 \pm 34.34$ & $40.59 \pm 26.03$ & $34.28 \pm 27.62$ & $18.85(35 \% \downarrow)$ & \multirow{2}{*}{$\begin{array}{l}\text { 6w: } p=0.01 \\
20 \mathrm{w}: p=0.05\end{array}$} \\
\hline & & c & $54.28 \pm 38.11$ & $54.02 \pm 43.00$ & $46.03 \pm 37.92$ & $-8.25(15 \% \downarrow)$ & \\
\hline \multirow{2}{*}{$\begin{array}{l}\text { Telephone-based cognitive } \\
\text { behavioral therapy }\end{array}$} & \multicolumn{2}{|c|}{ SX } & Baseline & 8 weeks & 24 weeks & MD (\%) & p value \\
\hline & \multirow{2}{*}{ Insomnia } & CBT-I & $15.6 \pm 0.8$ & $5.7 \pm 1.3$ & $4.9 \pm 1.2$ & $-10.7(71 \% \downarrow)$ & $<0.001$ \\
\hline \multirow{3}{*}{$\begin{array}{l}\text { Six CBT-I or MEC telephone } \\
\text { sessions in } 8 \text { weeks } \\
\text { Behavioral sleep plan Stimulus } \\
\text { control instructions, behavioral } \\
\text { sleep plan }\end{array}$} & & MEC & $16.8 \pm 1$ & $12.1 \pm 1.4$ & $9.4 \pm 1.7$ & $-7.4(46 \% \downarrow)$ & $<0.001$ \\
\hline & \multirow{2}{*}{$\begin{array}{l}\text { Hot } \\
\text { flashes }\end{array}$} & CBT-I & - & $\begin{array}{l}\text { Baseline } \\
-15.7 \pm 4.7\end{array}$ & $\begin{array}{l}\text { Baseline } \\
-22.8 \pm 5.9\end{array}$ & -22.8 & $=0.03$ \\
\hline & & MEC & - & $\begin{array}{l}\text { Baseline } \\
-7.1 \pm 7.5\end{array}$ & $\begin{array}{l}\text { Baseline } \\
-11.6 \pm 7.8\end{array}$ & -11.6 & $=0.003$ \\
\hline \multirow{2}{*}{$\begin{array}{l}\text { Telephone-guided self-help } \\
\text { cognitive behavioral therapy }\end{array}$} & \multicolumn{2}{|l|}{ Sx } & Baseline & 6 weeks & 3 month & MD (\%) & value \\
\hline & \multirow{2}{*}{$\begin{array}{l}\mathrm{HF} / \mathrm{NS} \\
\text { frequency }\end{array}$} & I & $55.52 \pm 38.34$ & $37.85 \pm 30.33$ & $28.54 \pm 27.55$ & $-26.98(48 \% \downarrow)$ & \multirow{2}{*}{$=0.001$} \\
\hline \multirow{3}{*}{$\begin{array}{l}\text { Women completed a Self-Help } \\
\text { CBT intervention (booklet and } \\
\text { relaxation/paced breathing CD) } \\
\text { during a 4-week period. women } \\
\text { also received one 'guiding' } \\
\text { telephone call from a clinical } \\
\text { psychologist two weeks into } \\
\text { treatment }\end{array}$} & & c & $56.69 \pm 50.43$ & $49.67 \pm 48.55$ & $44.05 \pm 45.18$ & $-12.64(22 \% \downarrow)$ & \\
\hline & \multirow{2}{*}{$\begin{array}{l}\text { HF/NS } \\
\text { problem } \\
\text { rating }\end{array}$} & I & $6.23 \pm 2.16$ & $3.74 \pm 1.87$ & $2.98 \pm 1.36$ & $-3.25(52 \% \downarrow)$ & \multirow{2}{*}{$<0.0001$} \\
\hline & & C & $5.79 \pm 2.76$ & $4.97 \pm 2.44$ & $4.18 \pm 2.45$ & $-1.54(26 \% \downarrow)$ & \\
\hline \multirow{5}{*}{$\begin{array}{l}\text { Self-help cognitive behavior } \\
\text { therapy } \\
\text { The material in booklet form; } \\
\text { and received a relaxation/paced } \\
\text { breathing CD during a 4-week } \\
\text { period }\end{array}$} & \multicolumn{2}{|l|}{ sx } & Baseline & 6 weeks & 26 weeks & MD (\%) & $\mathrm{p}$ value \\
\hline & \multirow{2}{*}{$\begin{array}{l}\mathrm{HF} / \mathrm{NS} \\
\text { problem } \\
\text { rating }\end{array}$} & I & $5.87 \pm 2.28$ & $3.79 \pm 0.58$ & $4.68 \pm 0.83$ & $-1.19(20 \% \downarrow)$ & \multirow{2}{*}{$\begin{array}{l}\text { 6w: } p<0.001 \\
\text { 26w: } p=0.001\end{array}$} \\
\hline & & c & $5.87 \pm 2.28$ & & & & \\
\hline & \multirow{2}{*}{$\begin{array}{l}\mathrm{HF} / \mathrm{NS} \\
\text { frequency }\end{array}$} & I & $63.15 \pm 49.24$ & \multicolumn{2}{|c|}{$\begin{array}{l}60.67 \pm 0.21 \text { Small significant } \\
\text { reduction }\end{array}$} & $-2.48(3.9 \% \downarrow)$ & \multirow{2}{*}{$\begin{array}{l}\text { Small } \\
\text { significant }\end{array}$} \\
\hline & & $\mathrm{C}$ & $63.15 \pm 49.24$ & & & & \\
\hline \multirow{2}{*}{$\begin{array}{l}\text { Self-help cognitive behavior } \\
\text { therapy }\end{array}$} & $\mathbf{s x}$ & & Baseline & 3 weeks & 26 weeks & MD (\%) & p value \\
\hline & HF/NS & I & $5.84 \pm 1.93$ & $2.96 \pm 1.76$ & $3.07 \pm 1.93$ & $-2.77(47 \% \downarrow)$ & \\
\hline udes a self- & & c & $5.79 \pm 2.76$ & $4.97 \pm 2.44$ & $4.18 \pm 2.45$ & $-1.61(27 \% \downarrow)$ & 05 \\
\hline $\begin{array}{l}\text { 4-week period and two contacts } \\
\text { with a clinical psychologist }\end{array}$ & & I & $70.68 \pm 57.49$ & $49.20 \pm 39.24$ & $44.94 \pm 42.70$ & $-25.74(36 \% \downarrow)$ & \\
\hline $\begin{array}{l}\text { one introductory session and a } \\
\text { guiding telephone call } 2 \text { week } \\
\text { into treatment) }\end{array}$ & frequency & C & $56.69 \pm 50.43$ & $49.67 \pm 48.55$ & $44.05 \pm 45.18$ & $-12.64(22 \% \downarrow)$ & \\
\hline
\end{tabular}

MRS: Menopause Rating Scale, "SX: The abbreviation of symptoms, **N.S: Not significant, DASS-21: The Depression Anxiety and Stress Scale, 
approaches can reduce over $70 \%$ of the initial insomnia score. Furthermore, in a study by Keefer and Blanchard (14) the intervention group was classified into two immediate and delayed treatment groups in the case of assessing night sweats, depression, and total vasomotor symptoms. Treatment sessions were designed weekly and consist of education, relaxation training, and cognitive restructuring. In this regard, they reported a positive effect in the group with immediate treatment but in the group whose treatrent was dedate tealt was the oppoite, and all of thes result was the oppore, a d al there increased. than twice the intial score. According to this finding, he start time of group therapyisnoiceable, and if the treament begins at a later stage, the result can be obtained in the opposite way (14)

Although in the study of Larroy García and Gómez-Calcerrada (4), the symptoms measured by the Kupperman and Blatt Menopausal index questionnaire separately did not have a significant alteration after group CBT, the total score represents a $20 \%$ decrease from the initial score, indicating the effectiveness of the group approach.

\section{Study limitation}

We were not able to perform a meta-analysis in the present study due to the alteration in the questionnaires used to measure the symptoms, and the difference in the implementation method, including the number of treatment sessions or the number of participants in the group meetings. Moreover, as a result of the low and moderate quality of most studies involved in this systematic review, more studies with high quality should be conducted in individual and self-help CBT approaches to measure the impact of these approaches on more varied symptoms of menopause.

It can be concluded that although the indirect method is more cost-effective, it has less impact than the face-to-face method, and if there are possibilities, it is better to use face-to-face approaches to achieve a better is belt However, in countes with less facilities, self-help CBT (indirect methods) can be beneficial.

Peer-review: Externally peer-reviewed.

Conflict of Interest: No conflict of interest was declared by the authors.

Financial Disclosure: The present study was supported by Shahroud University of medical sciences as a PhD Thesis. We hereby acknowledge the research deputy for grant No 9659 . Also, we hereby acknowledge from student research committee of Shahroud University of Medical Sciences.

\section{References}

1. Marín RM. Atención integral a la mujer de mediana edad. En: Sánchez-Cánovas J, coordinador- Ariel, 1996: 87-128.

Malacara JM. Prólogo. Revista de Endocrinología y Nutrición 2006; 14: 131-2.

3. Mast MS, Hornung R, Gutzwiller F, Buddeberg C. Sexualität in der 2000; 40: 13-9.

4. Larroy García C, Gómez-Calcerrada SG. Cognitive-behavioral intervention among women with slight menopausal symptoms: a pilot study. Span J Psychol 2011; 14: 344-55,

Caltabiano ML, Holzheimer M. Dispositional factors, coping and nopause. Climacteric 1999; 2: 21-8.

Gannon L, Hansel S, Goodwin J. Correlates of menopausal hot , 1987; 10: 277-85.

. Burkman RT. Berek \& Novak's gynecology. JAMA 2012; 308: 516-7. Nourolahi T, Ghaemi Z, Goodarzi HM, Naeneeni O, Jafari S, Ghaderi S, et al. 1390 national census of population and housing. Statistical

9. Manesh MJ, Moghadam Z. The experiences of menopause through Appl Sci $2011 ; 5: 1543-8$

10. MacLennan A, Lester S, Moore V. Oral oestrogen replacement therapy versus placebo for hot flushes. Cochrane Database Syst Rev 2001; CD002978.

11. Rossouw JE, Anderson GL, Prentice RL, LaCroix AZ, Kooperberg C,
Stefanick ML, et al. Risks and benefits of estrogen plus progstin in Stefanick ML, et al. Risks and benefits of estrogen plus progestin in Health Initititive randomized controlled trial. JAMA 2002; 288: 321-33.

12. Karimian Z, Keramat A. Hot Flashes of Menopause and Herbal Medicine in Iran: A Systematic Review. J of Iranian Obstetrics,

13. Ussher JM (edt). Body Talk: The Material and Discursive Regulation Keefer L Blanchard EB A behavioction. Routledge; 1997. menopausal hot flasses: results of a pilot study. Appl Psychophysiol Biofeedback 2005; 30: 21-30.

15. Blake F. Cognitive therapy for premenstrual syndrome. Cogn Behav

16. Blake F, Salkovskis P, Gath D, Day A, Garrod A. Cognitive therapy for
premenstrual syndrome: a controlled trial J J Psychosom Res 1998 : 45: $307-18$.

17. Hunter MS, Liao KLM. Evaluation of a four-session cognitivebehavioural intervention for menopausal hot flushes. Br J Health

18. Hunter MS, Ussher JM, Browne SJ, Cariss M, Jelley R, Katz M. A randomized comparison of psychological (cognitive behavior
therapy), medical (fluoxetine) and combined treatment for women with premenstrual dysphoric disorder. J Psychosom Obstet Gynaecol 2002; 23: 193-9.

19. Ayers B, Smith M, Hellier J, Mann E, Hunter MS. Effectiveness of group and self-help cognitive behavior therapy in reducing
problematic menopausal hot flushes and night sweats (MENOS 2): a randomized controlled trial. Menopause 2012; 19: 749-59.

20. Norton S, Chilcot J, Hunter MS. Cognitive-behavior therapy for menopausal symptoms (hot flushes and night sweats): moderator

11. Soori M, Koliowd $\mathrm{M}$, Mom Cognitive-Behavioral Therapy on alari N. The Effect of Group Women: A Randomized Clinical Trial. International J Life Science and Pharma Research 2018; 8: 12-9.
22. Yazdkhasti M, Simbar M, Abdi F. Empowerment and coping strategies in meno
$\mathrm{J} 2015 ; 17: \mathrm{e} 18944$
$\mathrm{~L}$

23. Larroy C, Marín C, Gutiérrez S. The effects of cognitive-behavioral techniques on hot flushes, depression and anxiety related to menopause in Spanish women. Wulfenia Journal 2015; 22.

24. Hunter M. Cognitive behavioural interventions for premenstrual and
menopausal symptoms. Journal of Reprod and Infant Psychology menopausal sym
2003; 21: $183-93$.

25. Tremblay A, Sheeran L, Aranda SK. Psychoeducational interventions to allevia.
$193-202$.

26. Stanley MA, Wilson NL, Novy DM, Rhoades HM, Wagener PD Greisinger AJ, et al. Cognitive behavior therapy for generalized anxiety disorder among older adults
clinical trial. JAMA 2009; 301: 1460-7.

27. Abdollahpour S, Keramat A, Mousavi SA, Khosravi A. The effect of debriefing and brief cognitive-behavioral therapy on postpartum depression in traumatic childbirth: a randomized 2018; 6: 1122-31.

28. Yoo MS, Lee H, Yoon JA. Effects of a cognitive-behavioral nursing intervention on anxiety and depression in women with breast cancer undergoing radiotherapy. J Korean Acad Nurs 2009, 39. 157-65.

29. Hunter MS, Coventry S, Hamed H, Fentiman I, Grunfeld EA. Evaluation of a group cognitive behavioural intervention for
women suffering from menopausal symptoms following breas cancer treatment. Psychooncology 2009; 18: 560-3.

30. Higgins JP, Altman DG, Gøtzsche PC, Jüni P, Moher D, Oxman AD, et al. The Cochrane Collaboration's tool for assessing risk of bias in
31. Hassan SA. Effectiveness of group cognitive behavioral therapy on depression among Iranian women around menopause. Australia

behavioral therapy in treatment of depression among Iranian women around menopause. Int $J$ Psychol Stud 2012; 4: 174.

33. Nowakowski S, Thurston R, Meers JM, Stout-Aguilar J, Sadruddin S, Hayman J, et al., editors. Cognitive Behavioral Therapy for
Menopausal Insomnia in Midlife Women with Insomnia and Nocturnal Hot Flashes. Menopauçse-The Journal of The North American Menopause Society; 2017: LippincottWillams \& Wilkins Two Commerce SQ, 2001 Market ST, Philadelphia, 19103

Green SM, Haber E, McCabe RE, Soares CN. Cognitive-behavioral group treatment for menopausal sym
Womens Ment Health 2013; 16: 325-32.

35. Alder J, Eymann Besken K, Armbruster U, Decio R, Gairing A, Kang A, et al. Cognitive-behavioural group intervention for climacteric

36. Hardy C, Griffiths A, Norton S, Hunter MS. Self-help cognitive and night sweats (MENOS $@$ Work): a multicenter randomized controlled trial. Menopause 2018; 25: 508-19.

37. McCurry SM, Guthrie KA, Morin CM, Woods NF, Landis CA, Ensrud $\mathrm{KE}$, et al. Telephone-Based Cognitive Behavioral Therapy for Insomnia in Perimenopausal and Postmenopausal Women With JAMA Intern Med 2016; 176: 913-20.

38. Stefanopoulou E, Hunter MS. Telephone-guided Self-Help Cognitive Behavioural Therapy for menopausal symptoms. Maturitas 2014; 